\title{
A second case of multivalent meiotic configurations in diploid species of Anura
}

\author{
Luciana Bolsoni Lourençol, Shirlei M. Recco-Pimentel ${ }^{1}$ and Adão José Cardoso ${ }^{2 *}$
}

\begin{abstract}
We analyzed the meiotic chromosomes of specimens from the two karyological groups of Physalaemus petersi (Jiménez de la Espada, 1872) described in the literature. Multivalent configurations (rings or chains) were observed in both groups. This meiotic organization resulted from the terminal association of non-homologous chromosomes, and an analysis of C-banded multivalents indicated no involvement of heterochromatic regions in these associations. A possible explanation for such meiotic configurations is the occurrence of heterozygous translocations. Thus, multivalents may indicate the involvement of translocation events in the karyotypic evolution of P. petersi.
\end{abstract}

\section{INTRODUCTION}

Terminal association of non-homologous bivalents at first meiosis has been described in many organisms. In some cases, such meiotic configurations arise from nonchiasmate interactions between $\mathrm{C}$-band positive ends and either euchromatic ends or other heterochromatic blocks of non-homologues (Drets and Stoll, 1974; John and King, 1982, 1985). On the other hand, several studies have shown multivalent configurations at first meiosis as a result of heterozygosity for either interchange or Robertsonian fusion or fission (John, 1987; Bidau and Mirol, 1988; Haaf et al., 1989; Moss and Murray, 1990; Mirol and Bidau, 1991, 1992, 1994; Reed et al., 1992). In all these cases, the associations between non-homologues were chiasmate. Meiotic configurations formed in this way can lead to irregular segregation and a high rate of nondisjunction, with a consequent reduction in reproductive potential (Eichenlaub-Ritter and Winking, 1990), although sometimes there may be no apparent negative influence on fertility (Mirol and Bidau, 1994).

In Anura, multivalent meiotic configurations formed by homologous chromosomes have been described in some polyploid species (Beçak et al., 1966, 1967, 1970; Schmid et al., 1985), but terminal association of non-homologous bivalents in meiosis was observed only in the leptodactylids Eleutherodactylus binotatus $(2 \mathrm{n}=22)$ (Beçak and Beçak, 1974) and Odontophrynus americanus $(4 \mathrm{n}=44)($ Beçak and Beçak, 1998). In E. binotatus, such configurations were considered to be indicative of multiple translocations and/or centric fusions, important mechanisms possibly related to the diploidization of an ancestral polyploid karyotype, giving rise to the diploid karyotype of this species (Beçak and Beçak, 1974). In the polyploid O. americanus, the multivalent configurations involving non-homologous chromosomes were attributed to a 4/11 translocation (Beçak and Beçak, 1998).
We have previously reported two distinct karyotypes (I and II), as well as C-band and NOR polymorphisms in the anuran Physalaemus petersi (Jiménez de la Espada, 1872) (Lourenço et al., 1998, 1999). The multiple NOR sites and non-centromeric C-bands detected could have resulted from translocation events. In the present work, we describe multivalent configurations in both karyological groups of $P$. petersi from the Brazilian Amazon and suggest that these arrangements provide cytological evidence for translocation events during the evolution of the two karyotypes.

\section{MATERIAL AND METHODS}

The meiotic chromosomes of 13 P. petersi males belonging to karyological group I (ZUEC 9584, 9586, 9588, 9589, 9593, 9595, 9596, 9597, 9598, 9613, 9632, $9633,9625)$ and two males belonging to karyological group II (ZUEC 9584, 9654) were examined. The group II specimens were collected in the Alto Juruá Reserve (Acre State, Brazil) in February, 1994, and January, 1996. Five group I animals were also collected in this region at the same time; the other eight specimens of this group were obtained from the Humaitá Reserve (Acre State, Brazil) in December, 1994, and April, 1995. All of the specimens were deposited in the Museum of Zoology at the State University of Campinas (ZUEC). Cytological preparations were obtained from cell suspensions of testes removed from animals treated with colchicine for $4 \mathrm{~h}$ (Schmid, 1978). Conventional staining with Giemsa and C-banding were done as described elsewhere (King, 1980).

\section{RESULTS}

In addition to 11 isolated bivalents (Figures 1a and 2a), multivalent rings and chains formed by the association of bivalent chromosomes were observed in diakinetic

Departamentos de ${ }^{1}$ Biologia Celular and ${ }^{2}$ Zoologia, Instituto de Biologia, Universidade Estadual de Campinas (UNICAMP), 13083-970 Campinas, SP, Brasil. Send correspondence to S.M.R.-P. Fax: +55-19-788-7821. E-mail: shirlei@obelix.unicamp.br *This paper is dedicated to the memory of Adão José Cardoso, who died before this work was completed. 
spermatocytes from eight group I and two group II specimens of P. petersi (Figures $1 \mathrm{~b}-\mathrm{g}$ and $2 \mathrm{~b}$ ). In two specimens (ZUEC 9588 and 9589) there were multivalent configurations that appeared to involve most of the chromosome pairs of the karyotypes (Figure 1d-f).

Both alternate and adjacent multivalents were seen in group I specimens (Figure 1b-d and 1g, respectively) whereas in group II animals only open chains were observed. The association between bivalents involved terminal regions and the $\mathrm{C}$-banded figures showed no participation of heterochromatic regions in these interactions (Figure 1g).

\section{DISCUSSION}

As previously reported (Lourenço et al., 1999), noncentromeric C-bands interfered with homologous chromosome behavior in meiosis. The heterozygosity of the telomeric and interstitial heterochromatic blocks seen in karyological group I specimens of $P$. petersi probably prevented pairing and/or crossing-over between homologous chromosome arms. Nevertheless, there was no evidence to support the involvement of non-centromeric heterochromatic blocks in the formation of multivalent configurations at first meiosis in this karyological group. The $\mathrm{C}$ banding technique showed no heterochromatin in the region of the bivalent associations. Generally, in cases where C-bands play a role in the origin of multivalent meiotic arrangements, the associations between two non-homologous chromosome pairs involve at least one terminal Cband (John and King, 1985). Although we did not conclusively determine the $\mathrm{C}$-banding pattern of all the specimens examined here, the haploid karyotype of group I $P$. petersi usually showed a maximum of four telomeric Cbands (Lourenço et al., 1999). This suggests that there are probably not enough C-blocks to support heterochromatic associations that can give rise to configurations such as that shown in Figure 1d, for example.

One possible explanation for these meiotic associations could be the existence of limited homology between non-homologous chromosomes in the group I karyotype. The pairing of such segments and the formation of chiasma between them would arrange the chromosomes in multiple configurations in the first meiosis. We hypothesize that multiple translocations could have been involved in the origin of such homologous segments in non-homologous chromosomes, as also suggested for the leptodactylid Eleutherodactylus binotatus (Beçak and Beçak, 1974). The variable relative size and arm ratio of the different morphs of chromosomes 6 and 8 (Lourenço et al., 1998, 1999) agree with this hypothesis since multiple translocations are expected to change the morphology of the chromosomes involved. Such multiple translocations probably played an important role in the karyotypic evolution of this species and could provide a mechanism for the appearance of multiple NOR and C-bands in
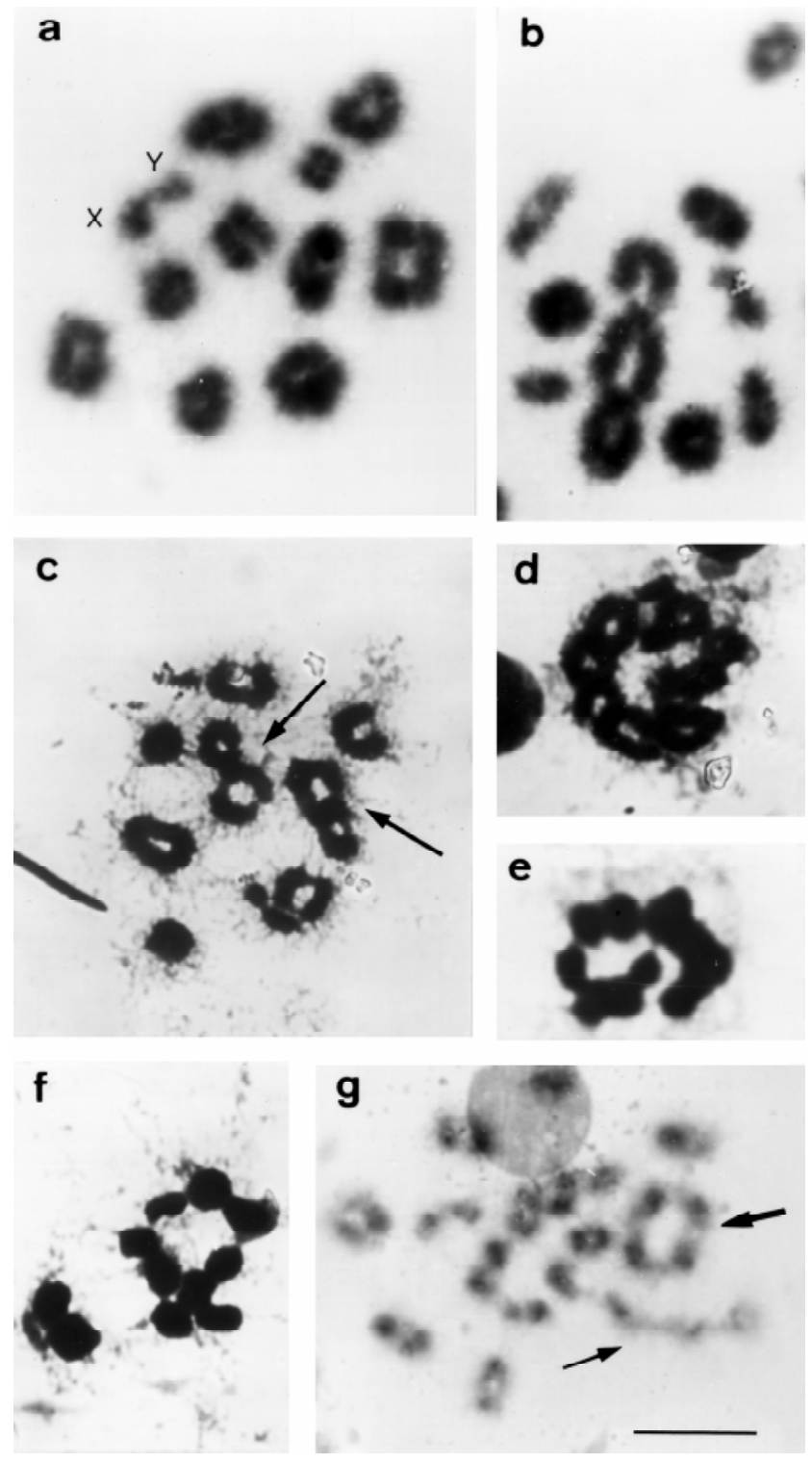

Figure 1 - Meiotic chromosomes of specimens of Physalaemus petersi belonging to karyological group I, stained with Giemsa (a-f) (bar $=10 \mu \mathrm{m})$ or Cbanded $(\mathbf{g})(\mathrm{bar}=10.3 \mu \mathrm{m})$. In $\mathbf{a}$, the 11 bivalents from one spermatocyte of specimen ZUEC 9595 showing no association between them; the sex chromosomes XY are indicated. In $\mathbf{b}$, another spermatocyte from the same specimen showing three associated bivalents. In c, two alternate quadrivalents (arrows) from specimen ZUEC 9588. In d-f, multivalents involving a great number of bivalents from specimens ZUEC 9588 (d, f) and ZUEC 9589 (e). In g, C-banded chromosomes from specimen ZUEC 9586. The adjacent quadrivalent (large arrow) and the linear chain (small arrow) are shown. Note also the absence of heterochromatin in the regions of association.

P. petersi, particularly in the group I karyotype. Although the occurrence of heterozygotes for translocations could also account for the multivalent chains observed in group II specimens, the absence of C-banded configurations precludes a reliable interpretation of this event. In any case, these unusual meiotic configurations make this group an interesting model for future cytological investigations. 




Figure 2 - Meiotic chromosomes from karyological group II specimens of Physalaemus petersi stained with Giemsa. In a, 11 isolated bivalents. In $\mathbf{b}$, associated bivalents forming two open multivalent chains. Bar $=10 \mu \mathrm{m}$.

\section{ACKNOWLEDGMENTS}

We thank the Brazilian agencies CAPES and CNPq for financial support, and Moisés Barbosa de Souza for helping in the field work. Publication supported by FAPESP.

\section{RESUMO}

Nós analisamos os cromossomos meióticos de espécimes dos dois grupos cariotípicos de Physalaemus petersi (Jiménez de la Espada, 1872) descritos na literatura. Configurações multivalentes (anéis e cadeias) foram descritas em ambos os grupos. Essa organização meiótica resultou da associação terminal de cromossomos não-homólogos e a análise de preparações meióticas submetidas ao bandamento $C$ não indicou o envolvimento de regiões heterocromáticas nessas associações. Uma possível explicação para tais configurações meióticas consiste na presença de translocações heterozigotas. Nesse caso, os multivalentes observados evidenciariam o envolvimento de eventos de translocação na evolução cariotípica em P. petersi.

\section{REFERENCES}

Beçak, M.L. and Beçak, W. (1974). Diploidization in Eleutherodactylus (Leptodactylidae-Amphibia). Experientia 30: 624-625.
Beçak, M.L. and Beçak, W. (1998). Evolution by polyploidy in Amphibia: new insights. Cytogenet. Cell Genet. 80: 28-33.

Beçak, M.L., Beçak, W. and Rabello, M.N. (1966). Cytological evidence of constant tetraploidy in the bisexual South American frog Odontophrynus americanus. Chromosoma 19: 188-193.

Beçak, M.L., Beçak, W. and Rabello, M.N. (1967). Further studies on polyploid amphibians (Ceratophrydidae). I. Mitotic and meiotic aspects. Chromosoma 22: 192-201.

Beçak, M.L., Denaro, L. and Beçak, W. (1970). Polyploidy and mechanisms of karyotypic diversification in Amphibia. Cytogenetics 9: 225-238.

Bidau, C.J. and Mirol, P.M. (1988). Orientation and segregation of Robertsonian trivalents in Dichroplus pratensis (Acrididae). Genome 30: 947-955.

Drets, M.E. and Stoll, M. (1974). C-banding and non-homologous associations in Gryllus argentinus. Chromosoma 48: 367-390.

Eichenlaub-Ritter, U. and Winking, H. (1990). Nondisjunction, disturbances in spindle structure, and characteristics of chromosome alignment in maturing oocytes of mice heterozygous for Robertsonian translocations. Cytogenet. Cell Genet. 54: 47-54.

Haaf, T., Winking, H. and Schmid, M. (1989). Immunocytogenetics. II. Analysis of trivalent and multivalent configurations in mouse pachytene spermatocytes by human autoantibodies to synaptonemal complexes and kinetochores. Cytogenet. Cell Genet. 50: 6-13.

John, B. (1987). The orientation behaviour of multiple chromosome configurations in acridid grasshoppers. Genome 29: 292-308.

John, B. and King, M. (1982). Meiotic effects of supernumerary heterochromatin in Heteropternis obscurella. Chromosoma 85: 39-65.

John, B. and King, M. (1985). Pseudoterminalisation, terminalisation, and non-chiasmate modes of terminal association. Chromosoma 92: 89-99.

King, M. (1980). C-banding studies on Australian hylid frogs: secondary constriction structure and the concept of euchromatin transformation. Chromosoma 80: 191-217.

Lourenço, L.B., Recco-Pimentel, S.M. and Cardoso, A.J. (1998). Polymorphism of the nucleolus organizer regions (NORs) in Physalaemus petersi (Amphibia, Anura, Leptodactylidae) detected by silver-staining and fluorescence in situ hybridization. Chromosome Res. 6: 1-9.

Lourenço, L.B., Recco-Pimentel, S.M. and Cardoso, A.J. (1999). Two karyotypes, heteromorphic sex chromosomes and C-band variability in Physalaemus petersi (Anura, Leptodactylidae). Can. J. Zool. (in press).

Mirol, P.M. and Bidau, C.J. (1991). Meiotic behavior of Robertsonian heterozygotes in populations of Dichroplus pratensis (Acrididae). Genetica 84: 171-178.

Mirol, P.M. and Bidau, C.J. (1992). Proximal chiasmata induce nondisjunctional orientation of Robertsonian trivalents in a grasshopper. Heredity 69: 268-278.

Mirol, P.M. and Bidau, C.J. (1994). Non-random patterns of non-disjunctional orientation in trivalents of multiple Robertsonian heterozygotes of Dichroplus pratensis (Acrididae). Genetica 92: 155-164.

Moss, J.M. and Murray, B.G. (1990). The three-dimensional arrangement of chromosomes at meiotic metaphase I in normal and interchange heterozygotes of Briza humilis. J. Cell Sci. 97: 565-570.

Reed, K.M., Sites, J.W. and Greenbaum, I.F. (1992). Synapsis, recombination, and meiotic segregation in the mesquite lizard, Sceloporus grammicus, complex. II. Fission heteromorphism of the FM2 cytotype and evolution of chromosome 2. Cytogenet. Cell Genet. 61: 46-54.

Schmid, M. (1978). Chromosome banding in Amphibia. I. Constitutive heterochromatin and nucleolus organizer regions in Bufo and Hyla. Chromosoma 66: 361-388.

Schmid, M., Haaf, T. and Schempp, W. (1985). Chromosome banding in Amphibia. IX. The polyploid karyotypes of Odontophrynus americanus and Ceratophrys ornata (Anura, Leptodactylidae). Chromosoma 91: 172-184.

(Received December 7, 1998) 
